\title{
Improve the Quality of Graduate Student's Management Combined with Agricultural Characteristics
}

\author{
Yang $\mathrm{Da}^{1, \mathrm{a}}$ \\ ${ }^{1}$ Jilin Agricultural University, Jilin 130000, China \\ ayangnan1983116@163.com
}

Keywords: Graduate student, the quality of education, cultivate.

\begin{abstract}
In China, graduate education is shouldering the important task of training high quality talents and high-level creative talents for modernization construction. Graduate education will become the construction of national innovation system in our country and the key support to seize the commanding heights of the knowledge economy in the future. This paper analyzes the important effect of teaching quality in graduate education. This paper puts forward some corresponding suggestions to the current problems which are existing in the quality of graduate education in colleges and universities.
\end{abstract}

\section{Introduction}

Graduate students are the innovation forces of scientific research. The graduate education as a graduate student's education subsystem and a separate level of higher education, its quality relates to the graduate education and the development of higher education. Since the enrollment expansion in 1999, the graduate education of our country gradually revealed many contradictions and problems. The main expression is: (1)Some graduate students' study style is not straight. (2)Some educating units loose managements and relax requirements. Under the drive of economic benefits, a few training units take formalism. Some students even spend money on degree. These problems if not solved what will affect the quality of graduate education in our country and even hinder the overall development of higher education. At present, most graduate students take a combination of taking course and researching scientific, strengthening the professional theory, cultivating the comprehensive quality and practical ability. Its purpose is to make students become national high-quality talents who is good at scientific research, college teaching, specialized technical design and management ability. We must attach importance to the quality of graduate cultivation as the lifeline of graduate education. The management work of graduate student education focus to improve training quality.

\section{The Present Problems of Graduate Education}

According to the current and national ministry spirit of education, graduate education takes the applied talent as the principal part, doctor-postgraduate education takes the academic talent as the principal part. The universities should take the knowledge system of first-level discipline as the the principal part and take the knowledge system of second-degree subject as the characteristic part. The universities should teach students in accordance of their aptitude and take the principle of cultivation of personality. The graduate cultivation should highlight the practical ability of application, the doctorpostgraduate cultivation should highlight academic ability. Through the analysis found that the present problem of graduate education has the following several aspect: (1) The graduate management in most colleges and universities lack necessary teaching staff compared to undergraduate. Or the level of teachers troop is not high and they don't conform to the characteristics of graduate education management. (2) The age span of graduate student is larger and the level of graduate student is different. There are a lot of students don't like academic, they just mix diploma. A few years down, there is no growth on ability or knowledge of graduate student. 
(3) Many schools does not have education level of graduate student due to the teachers, the level of laboratory and academic level are low. But teachers set up related specialties after assemble some different disciplines and make the different disciplines be in a region without respect the differences among disciplines. Discipline directions are multifarious what have no cohesion and no motive force of sustainable development. Even in some universities, the teachers' levels are different and professional developments are different. All these situations reduce the education quality of graduate student.

\section{Suggestions for Improving the Quality of Graduate Education}

The department of graduate education should strengthen and improve graduate education management and do a good job on graduate education according to taking quality as the core. To improve the quality of graduate education is the important guarantee. The department of graduate education has to adjust the schooling, revise training plan, reform enrollment system and the teacher appointment system. To strengthen the construction of quality guarantee system from several aspects such as and improve the quality of teaching.

To revise training plan and strengthen the training process combined with the current situation. All kinds of full-time graduate training scheme and link set should reflect the wide scope of the applied talents training and practical characteristics. The field of professional features obviously or closely related to the qualifications degree type should be separately formulated training scheme for industrial system. According to the actual situation to set up graduate student's education steering committee, training plan, approval of course syllabus. To supervise the teaching and graduate training links and strengthen the guidance for the work of graduate education and the management of training process.

The education department should reform enrollment system and improve the quality of students. The process of graduate admissions should be fully embody the course requirements and teacher autonomy and must be strictly grasp and meet the selection criteria and procedures. Let the graduate admissions process be transparent and attract more students who really has research potential and ambition in further studying. According to the specific circumstances, the universities can gradually increase the school recommend study for a master's graduate student enrollment. At the time of recruitment, raise the proportion to attend the second interview candidates on the basis of the unified interview as fractional line. The institutions can also determine the proportion second interview according to the actual situation. On one hand, the institutions can provide more opportunities for students. On the other hand, the institutions can also be integrated more candidates in all kinds of situation to admit the best examinee.

Reform the teacher's management to highlight job ability. Reform the graduate teacher's employment management and carry out the qualification inspection system of graduate enrollment and professional training of mentor on graduate education, academic moral construction and project funded by the post responsibility. And according to the supervisor's research level and cultivation ability to determine the annual quota allocation. The total number of master graduate students of every teacher in school no more than 15 people. Dissertation evaluation mechanism is established to guide the graduate paper quality problems, the anomie of academic morality mentor for serious processing. Reduce the student enrollment and even stop recruit students as appropriate.

The universities should improve the innovation ability of graduate student and cultivate the pioneering spirit of graduate student. Innovation is the important content of graduate education. The universities should pay attention to train graduate student's ability of practice innovation and use multi-channel, multi-mode what is combined with the training of graduate student's practice innovation. The universities should actively carry out academic report and employ academic attainments of experts and scholars to the lecture both at home and abroad. The teachers take academic exchanges on the subject at school. To organize various academic BBS such as Master of BBS, Salon, etc.. These will greatly promote the graduate student's science consciousness and academic interest. Then to cooperate with international famous universities. The universities need

cultivate more forms to strengthen the graduate student of international cooperation. The 
universities should standardize graduate student's class teaching, strengthen the public course and degree of quality construction, establish and improve the graduate student's curriculum teaching procedures, encourage bilingual teaching, research-based teaching and explorative teaching for graduate students and stress the cultivation of innovation ability on graduate classroom teaching.

The graduate student's management work should make a confirming orientation. The task of graduate student on education management is to create favorable environment for graduate's study and research. The management departments lack of knowledge on education and management because the staffs are graduated different majors. Therefore, the departments of education management need to hold some classes, seminars and training courses with a variety of forms in conjunction with the degree and graduate education at all levels for executives. Let them study pedagogy, management, relevant state policies and regulations. The more important is to strengthen their service consciousness for graduate students.

\section{Conclusion}

To cultivate the graduate student who has independence, innovation and enthusiasm in the new period. This is the need of economic development and core of management on graduate student's project in universities. The graduate student's managers should reform the teaching management mode, the way of scientific research management and daily management mode to promote the vigorous development of graduate education in colleges and universities.

\section{Acknowledgments}

First of all, I'd like to take this opportunity to show my sincere gratitude to my supervisor who has given me so much useful advices on my writing, and has tried his best to improve my paper. Secondly, I'd like to thank those leaders, teachers and working staff . Without their help, it would be much harder for me to finish my study and this paper.

\section{References}

[1] Allan M. Canter, An assessment of quality in graduate education, American Council on Education, 1996.

[2] Jennifer Grant Haworth, Emblems of Quality in Higher Education.,Allyn\&Bacon, 1997. 